\title{
EFFECT OF ENTEROCINS CCM4231 AND V24 ON THE CELLS OF ENVIRONMENTAL ISOLATES Acinetobacter spp.
}

\author{
A. LAUKOVÁ \\ Institute of Animal Physiology Slovak Academy of Sciences, Košice, Slovak Republic
}

Received April 11, 2001

Accepted October 31, 2001

Abstract

Lauková A.: Effect of Enterocins CCM4231 and V24 on the Cells of Environmental Isolates Acinetobacter spp. Acta Vet. Brno 2001, 70: 473-477.

The inhibitory effect of bacteriocins (enterocins) produced by different enterococcal isolates against Acinetobacter spp. strains AL1 and AL115 and/or on the resting cells of AL1 strain was tested under in vitro conditions. These poly-resistant strains (resistant to 6 from 12 antibiotics) were isolated from the cattle dung water and feces from chamois. Their growth was inhibited by treatment of crude extracts of enterocins CCM4231, V24, EC24, EK13 with activity ranged from 100 to 1600 Arbitrary units per $\mathrm{ml}$. When log phase cells of Acinetobacter spp. AL1 strain were treated by crude extracts (CE) CCM4231 and V24 at temperatures $4{ }^{\circ} \mathrm{C}$ and $33^{\circ} \mathrm{C}$, the decrease of surviving cells in comparison to the control, one order of magnitude was found. In contrary, when exponential phase cells were harvested and treated by CE CCM4231 and V24, at $4{ }^{\circ} \mathrm{C}$ no reduction was noted. While at $33^{\circ} \mathrm{C}$ the decrease of cells 2 orders and one order of magnitude was measured. Here, the effect of some enterocins against Gram-negative bacteria was confirmed as well as the way for further experiments to apply enterocins for the control and/or for maintaining the microbial balance in waste ecosystem.

Bacteriocins, excrements, Acinetobacter spp., anti-microbial effect

Livestock management is associated with liquid and solid manure production. The manure possesses a fertilizing value that should be used as much as possible to replace expensive chemical fertilizers. However, the excessive utilization of animal manures in agriculture has resulted, in some areas of Europe with dense animal populations, in serious environmental pollution (Strauch and Ballarini 1994). That is, the manure is a source of different Grampositive and Gram-negative microorganisms, the pathogenic species including (Lauková et al. 2000a). Animal as well as public health hazard is faced in front of possibilities of diseases transmission. Genus Acinetobacter involves Gram-negative, oxidase-negative, nonmotile rods taxonomically allotted to the Family Moraxellaceae which are ubiquitously distributed in the environment (Bifulco et al. 1989; Rossau et al. 1991). They were detected even in the activated sludge (Rossetti et al. 1997). Bergogne-Berezin (1995) presented the increasing significance of outbreaks of Acinetobacter $\mathrm{spp}$. Therefore, there are the impacts leading to search for methods that would be more effective against surviving contaminants. In this paper, the effect of bacteriocins (enterocins) produced by ruminal and environmental enterococci is reported. Moreover, the effect of enterocins CCM4231 and V24 produced by Enterococcus faecium CCM4231 and Ent. faecalis V24 strains on resting cells of Acinetobacter spp. AL1 strain is included. The aim of this study resulted from our previous studies using CCM4231 and V24 bacteriocins to reduce contaminant bacteria in cattle dung water or slurry (Lauková et al. 1998; Lauková et al. 2000b).

\section{Materials and Methods}

Strains, media and growth conditions

The strains of Acinetobacter spp. were isolated from cattle dung water as well as from feces of chamois by standard microbiological dilution method. Selected isolates were maintained on Trypticase soy broth and agar

Address for correspondence:

MVDr. Andrea Lauková, PhD Institute of Animal Physiolog Soltest
Phone: +421/55/6330283 Fax: +421/55/6782162 http://www.vfu.cz/acta-vet/actavet.htm 
enriched with $0.6 \%$ of yeast extract (TSB, TSA and with $5 \%$ of defibrinated sheep blood, Becton \& Dickinson, Cockeysville, USA) at $30^{\circ} \mathrm{C}$ and $37^{\circ} \mathrm{C}$ for $24 \mathrm{~h}$ and $48 \mathrm{~h}$. Phenotypic identification of species was done by BBL Crystal ID System - Enteric/Nonfermenter Gram -negative ID kit (Becton \& Dickinson).

Antibiotic sensitivity and/or resistance testing

Resistance and/or sensitivity to antibiotics was checked by agar diffusion method (B au er et al. 1966) according to the guidelines of the National Committee for Clinical Laboratory standards (1988) on Trypticase soy agar enriched with $5 \%$ of defibrinated sheep blood using antibiotic discs. Discs were purchased from Becton \& Dickinson and the following concentrations were used: gentamicin, ampicillin (GEN, AMP - $10 \mu \mathrm{g}$ ), erythromycin (ERY - $15 \mu \mathrm{g}$ ), kanamycin, tetracycline, rifampicine, vancomycin, streptomycin, chloramphenicol, cefalotine, penicillin (KAN, TCT, RIF, VAN, STR, CHC, CEF, PNC - $30 \mu \mathrm{g}$ ) and bacitracin (BAC - 2 units). Inhibition zone diameters were measured after $18 \mathrm{~h}-24 \mathrm{~h}$ of incubation at $37{ }^{\circ} \mathrm{C}$ of the strains tested. The standard strain, Staphylococcus aureus ATCC 6538, was incubated simultaneously as a control.

Preparing of the crude bacteriocin extracts (enterocins)

To test in vitro activity of bacteriocins (enterocins) against Acinetobacter spp., their crude extracts (CE) were prepared. However, for this test CE of several bacteriocin - producing enterococci (such as Enterococcus faecium CCM4231, EK13, Enterococcus casseliflavus EC24, Enterococcus faecalis V24) were used. CE were prepared as follows: enterococci were grown for $18 \mathrm{~h}$ at $37^{\circ} \mathrm{C}$ in MRS broth (Becton \& Dickinson). Cell-free supernatant fluids were collected by centrifugation $\left(30 \mathrm{~min}\right.$ at $10000 \mathrm{~g}$ ), treated by EDTA, heated for $30 \mathrm{~min}$ at $80{ }^{\circ} \mathrm{C}$, cooled and concentrated in a rotary evaporator. Before testing of these CE against Acinetobacter spp., their efficacy against the most sensitive indicator organism (Listeria innocua Li1, Hans Blom, Matforsk, Norway) was checked by the critical dilution method using agar spot test (De Vuyst et al. 1996) on Trypticase soy agar with $0.6 \%$ of yeast extract $(1.5 \%$ and $0.7 \%$, w/v). And, an inhibitory activity was defined as the reciprocal of the highest dilution which demonstrated complete inhibition of the indicator and expressed in Arbitrary units (AU) per millilitre of culture medium.

Effect of the crude bacteriocin extracts CCM 4231 and V24 on resting cells of Acinetobacter spp. AL 1

Cells of a middle logarithmic (mid-log) phase and/or exponential phase culture of Acinetobacter spp. AL1, grown in Trypticase soy broth with $0.6 \%$ of yeast extract at $37^{\circ} \mathrm{C}$, were harvested, washed with PBS-buffer pH 7.0 and resuspended to an O.D. of 1.0 in this buffer. $800 \mathrm{AU} \mathrm{ml}^{-1}$ of CE CCM4231 and V24 were added to the cell suspensions. After $30 \mathrm{~min}$ at $33^{\circ} \mathrm{C}$ as well as $4{ }^{\circ} \mathrm{C}$ the number of surviving cells was determined. The cell number was also checked from the control samples (without CE addition). The cells survival was checked on TSYA with $0.5 \%$ of defibrinated sheep blood and with trypsine $\left(1 \mathrm{mg} \mathrm{ml}^{-1}\right)$ and expressed in colony forming units per $\mathrm{ml}(\mathrm{cfu}$ $\mathrm{ml}^{-1}$ ). Acinetobacter spp. can grow also under low temperatures. That is, the incubation at low and optimal temperatures was tested to detect an inhibitory activity of CE from the point of their further possible application.

AL1 strain was selected for this experiment because of its better ability to grow in media.

\section{Results and Discussion}

On the basis of phenotypic studies the isolates were allotted to Acinetobacter spp. They were found to be oxidase-negative, catalase-positive with positive p-nitro-DLphenylalanine reaction which is typical for Acinetobacter spp. However, developed from these results, they cannot be detaily specified to the species level. The defined isolates were marked as Acinetobacter spp. AL1 and AL115. Exact specification of Acinetobacter spp., e. g. by the method such as sodium dodecyl sulfate-polyacrylamide gel electrophoresis or colony hybridization with a genus-specific 16S rRNA-targeted alkaline phosphataselabeled oligonucleotide probe by Guardabassi et al. (1998) or by Ellis et al. (1998) confirmed the frequent occurrence of this genus in the wastes. However, the strains of Acinetobacter spp. are not only contaminant bacteria. They can play an important role in horizontal gene transfer in soil microcosms and so to be a mechanism for bacterial adaptation to changing environments (Nielsen et al. 2000). Some of Acinetobacter spp. can even participate in degradation of phenol in the environment.

Both strains of Acinetobacter spp. presented in this study were poly-resistant with their resistance to following antibiotics: ampicillin, erythromycin, vancomycin, penicillin, chloramphenicol and bacitracin. It means, they showed resistance to 6 from 12 antibiotics used. Their remarkable ability to be and/or to develop resistance to antimicrobial agents, 
makes these microorganisms particularly suitable for monitoring antibiotic resistance in the environment (Towner 1997; Guardabassi et al. 1998). The presence of antibioticresistant bacteria e. g. in cattle dung or in the waste system derived from use of antibiotics in animal husbandry or in agriculture. It assesses the ecological impact from the view to maintain an ecological balance concerning to bacterial flora in nature.

However, concerning our aspect (the occurrence of Acinetobacter spp. in animal waste which can be used for land application), the method how to reduce their frequency in the environment mentioned is searched. That is why the treatment by bacteriocins was also applied against the isolates under in vitro conditions in this study. CE produced by EC24 strain inhibited both Acinetobacter isolates reaching activity 800 and $100 \mathrm{AU} \mathrm{ml}^{-1}$ (Table 1). Using CE EK13, the isolates were inhibited by activity 400 and $1600 \mathrm{AU} \mathrm{ml}^{-1}$. When $\mathrm{CE}$ V24 and CCM4231 was used to treat AL115 strain, the activity $100 \mathrm{AU} \mathrm{ml}^{-1}$ was measured. In the case of AL1 strain it was 100 and $400 \mathrm{AU} \mathrm{ml}^{-1}$. That is, the inhibitory activity of bacteriocins (enterocins) produced by enterococci against Gram-negative bacteria was found as previously reported by Lauková et al. (1993, 1998a, 2000c).

Table 1

Treatment of two strains of Acinetobacter spp. by enterocins

\begin{tabular}{|c|c|c|c|c|}
\hline Acinetobacter spp. & EK131 & V242 & EC243 & CCM42314 \\
\hline AL1 & $400^{*}$ & 100 & 800 & 400 \\
\hline AL115 & 1600 & 100 & 100 & 100 \\
\hline
\end{tabular}

${ }^{1}$ Crude extract/CE (enterocin) of Enterococcus faecium EK13; ${ }^{2} \mathrm{CE}$ of Ent. faecalis V24; ${ }^{4} \mathrm{CE}$ of Ent. faecium CCM4231. *Inhibitory (bacteriocin) activity is expressed in Arbitrary units per $\mathrm{ml}\left(\mathrm{AU} \mathrm{ml}{ }^{-1}\right)$.

Table 2

Effect of crude extracts (enterocins) CCM4231 and V24 on resting cells of Acinetobacter sp. AL1 harvested in log growth phase

\begin{tabular}{|l|c|c|c|}
\hline Control at $4{ }^{\circ} \mathrm{C}^{1}$ & Sample $+\mathrm{CE} \mathrm{CCM} 4231$ at $4{ }^{\circ} \mathrm{C}^{2}$ & Sample $+\mathrm{CE} \mathrm{CCM} 4231$ at $33^{\circ} \mathrm{C}^{3}$ & Control at $33{ }^{\circ} \mathrm{C}^{4}$ \\
\hline $2.4 \times 10^{8}$ & $1.0 \times 10^{7}$ & $1.2 \times 10^{7}$ & $1.8 \times 10^{8}$ \\
\hline Control at $4{ }^{\circ} \mathrm{C}$ & Sample $+\mathrm{CE} \mathrm{CCM} 4231$ at $4{ }^{\circ} \mathrm{C}^{6}$ & Sample $+\mathrm{CE} \mathrm{CCM} 4231$ at $33^{\circ} \mathrm{C}^{7}$ & Control at $33^{\circ} \mathrm{C}^{8}$ \\
\hline $2.4 \times 10^{8}$ & $5.0 \times 10^{7}$ & $2.8 \times 10^{7}$ & $1.8 \times 10^{8}$ \\
\hline
\end{tabular}

The number of surviving cells is expressed in cfu ml ${ }^{-1}$. ${ }^{1}$ Harvested cells of AL1 strain resuspended in PBS-buffer cultivated at $4{ }^{\circ} \mathrm{C}$ for $30 \mathrm{~min} .{ }^{2} \mathrm{Cells}$ of AL1 strain treated by crude extract (enterocin) CCM4231; cultivation at 4 ${ }^{\circ} \mathrm{C} .{ }^{3} \mathrm{Cells}$ of AL1 strain without enterocin; cultivation at $33^{\circ} \mathrm{C} .{ }^{4} \mathrm{Cells}$ of AL1 strain treated by enterocin CCM4231; cultivation at $33{ }^{\circ} \mathrm{C} .{ }^{5,7} \mathrm{Cells}$ of AL1 strain without enterocin V24; cultivation at $4{ }^{\circ} \mathrm{C}$ and $33{ }^{\circ} \mathrm{C}$. ${ }^{6,8} \mathrm{Cells}$ of AL1 strain treated by enterocin V24; cultivation at $4{ }^{\circ} \mathrm{C}$ and $33{ }^{\circ} \mathrm{C}$.

Effect of CE CCM4231 and V24 on resting cells of Acinetobacter spp. AL1 is given in Table 2 and Table 3 . When AL1 strain was harvested in a mid-log phase, resuspended in PBS-buffer and treated by CE CCM4231 and V24 individually, a decrease in the viable cell number of one order of magnitude was noted (from $10^{8} \mathrm{cfu} \mathrm{m}^{-1}$ to $10^{7} \mathrm{cfu} \mathrm{ml}^{-1}$ ) under both cultivation temperatures $\left(4^{\circ} \mathrm{C}\right.$ and ${ }^{\circ} 33 \mathrm{C}$ ). On the other hand, when AL1 strain was harvested in an exponential phase, treatment by CE CCM4231 as well as V24 at concentrations mentioned above showed the reduction in the viable cell number of 2 orders as well as one order of magnitude at a temperature of $33^{\circ} \mathrm{C}$ (from $10^{9}$ to $10^{7} \mathrm{cfu}$ $\mathrm{ml}^{-1}$ and/or from $10^{8}$ to $10^{7} \mathrm{cfu} \mathrm{ml}^{-1}$ ). In contrary, at $4{ }^{\circ} \mathrm{C}$, no inhibition in cells number from exponential phase growth was counted. The best inhibitory effect of enterocins against indicator bacteria affected in a log phase of their growth during batch cultivation was also reported in our previous studies (Lauková et al. 1999, Lauková and 
Table 3

Effect of crude extracts (enterocins) CCM4231 and V24 on resting cells of Acinetobacter sp. AL1 harvested in exponential growth phase

\begin{tabular}{|l|c|c|c|}
\hline Control at $4{ }^{\circ} \mathrm{C}^{1}$ & Sample $+\mathrm{CE} \mathrm{CCM} 4231$ at $4{ }^{\circ} \mathrm{C}^{2}$ & Sample $+\mathrm{CE} \mathrm{CCM} 4231$ at $33{ }^{\circ} \mathrm{C}^{3}$ & Control at $33{ }^{\circ} \mathrm{C}^{4}$ \\
\hline $3.7 \times 10^{8}$ & $1.1 \times 10^{8}$ & $6.5 \times 10^{7}$ & $1.2 \times 10^{9}$ \\
\hline Control at $4{ }^{\circ} \mathrm{C}^{5}$ & Sample $+\mathrm{CE} \mathrm{V} 24$ at $4{ }^{\circ} \mathrm{C}^{6}$ & Sample $+\mathrm{CE} \mathrm{V} 24$ at $33^{\circ} \mathrm{C}^{7}$ & Control at $33^{\circ} \mathrm{C}^{8}$ \\
\hline $3.7 \times 10^{8}$ & $1.2 \times 10^{8}$ & $7.8 \times 10^{7}$ & $1.2 \times 10^{9}$ \\
\hline
\end{tabular}

The number of surviving cells is expressed in cfu ml ${ }^{-1} \cdot{ }^{1,3}$ Cells of AL1 strain harvested in exponential growth phase and reusupended in PBS-buffer; cultivation at $4{ }^{\circ} \mathrm{C}$ and $33^{\circ} \mathrm{C} .{ }^{3,4} \mathrm{Cells}$ of AL1 strain harvested in exponential growht phase, resuspended in PBS-buffer and treated by enterocin (CE) CCM4231; cultivation at both temperatures. ${ }^{5,7}$ Cells of AL1 strain without enterocin V24; cultivation at both temperatures. ${ }^{1,8}$ Cells of AL1 strain treated by enterocin V24; cultivation at both temperatures.

Czikková 1999). However, the aspect of temperature and sensitivity of the indicator organism (structure of cell wall, etc.) must be also taken into account.

In conclusion, the cell number of Acinetobacter spp. AL1 strain in a mid - log phase was inhibited by $\mathrm{CE}$ of enterocins tested under both low and optimal temperatures $\left(4^{\circ} \mathrm{C}\right.$ and $33{ }^{\circ} \mathrm{C}$ ). When AL1 strain was harvested in an exponential phase of growth, enterocins reduced its cells count at the temperature of $33^{\circ} \mathrm{C}$ only. All CE inhibited both Acinetobacter spp. by activity ranged from 100 to $1600 \mathrm{AU} \mathrm{ml}^{-1}$. It indicates the correct direction and/or way to continue in the experiments with enterocins applying in wide range of treatment associated with environmental and/or agricultural microbiology or biotechnology.

\section{Účinok enterocínov CCM4231 a V24 na bunky environmentálnych kmeňov Acinetobacter spp.}

Bol testovaný inhibičný účinok bakteriocínov (enterocínov) produkovaných rôznymi enterokokmi na bunky ( $\mathrm{z}$ tzv. strednej logaritmickej a exponenciálnej fázy rastu) environmentálnych izolátov Acinetobacter spp. AL1 a AL115 za podmienok in vitro. Tieto polyrezistentné kmene (s rezistenciou na 6 z 12 testovaných antibiotík) boli izolované z hnojovice hovädzieho dobytka a z faeces kamzíkov. Ich rast bol inhibovaný tzv. ,hrubými extraktmi“ (HE) bakteriocínov - enterocínov (CCM4231, V24, EC24 a EK13) s aktivitou v rozsahu 100 až 1600 Arbitrárnych jednotiek (AU ml ${ }^{-1}$ ). Pri ošetrení buniek kmeňa Acinetobacter spp. AL1 (zo strednej logaritmickej fázy rastu) enterocínmi CCM4231 a V24 pri teplotách $4{ }^{\circ} \mathrm{C}$ a $33^{\circ} \mathrm{C}$, bol zistený pokles prežívajúcich buniek v porovnaní $\mathrm{s}$ kontrolou o jeden matematický rád. Naproti tomu, bunky z exponenciálnej fázy rastu kmeňa AL1 boli inhibované resp. redukované len pri teplote $33^{\circ} \mathrm{C}$ (o 2 a jeden matematické rády). Pri teplote $4{ }^{\circ} \mathrm{C}$ nebola zaznamenaná redukcia buniek kmeňa AL1. Uvedené výsledky potvrdili inhibíciu Gram-negatívnych baktérií enterocínmi a naznačili správnosí aplikačného testovania enterocínov pre ich využitie na kontrolu mikrobiálnej rovnováhy v ekosystéme exkrementov.

Acknowledgements

This work was financially supported by the Slovak Scientific Agency VEGA (project 2/6106/21). The author thanks to Mrs. Janka Lecáková for her technical assistance.

\section{References}

BERGOGNE-BEREZIN, E. 1995: The increasing significance of outbreaks of Acinetobacter spp.: the need for control and new agents. J. Hosp. Infect. 30: 441-452

BIFULCO, J. M., SHIREY, J. J., BISSONETTE, G. K. 1989: Detection of Acinetobacter spp. in rural drinking water supplies. Appl. Environ. Microbiol. 55: 2214-2219

BAUER, A. W., KIRBY, W. M. M., SHERRIS J. C., TURCK, M. 1966: Antibiotic susceptibility testing by standardized single disk method. Am. J. Clin. Path. 45: 493-496 
DE VUYST, L., CALLEWAERT, R., POT, B. 1996: Characterization and activity of Lactobacillus amylovorus DCE471 and large scale isolation of its bacteriocin amylovorin L471. System. Appl. Microbiol. 19: 9-20

ELLIS, T. G., HIGGINS, M. J., KAISER, S. K., COWAN, R. M., SCHMIT, CH. G. 1998: Activated sludge and other suspended culture processes. Water Environ. Res. 70: 473-495

GUARDABASSI, L., PETERSEN, A., OLSEN, J.E., DALSGAARD, A. 1998: Antibiotic resistance in Acinetobacter spp. isolated from sewers recieving waste effluent from a hospital and a pharmaceutical plant. Appl. Environ. Microbiol. 64: 3499-3502

LAUKOVÁ, A., MAREKOVÁ, M., JAVORSKÝ, P. 1993: Detection and antimicrobial spectrum of a bacteriocinlike substance produced by Enterococcus faecium CCM4231. Lett. Appl. Microbiol. 16: 257-260

LAUKOVÁ, A., CZIKKOVÁ, S. 1998b: Inhibition effect of enterocin CCM4231 in the rumen fluid environment. Lett. Appl. Microbiol. 26: 215-218

LAUKOVÂ, A., CZIKKOVÁ, S., VASILKOVÁ, Z., JURIŠ, P., KRUPICER, I. 1998a: Antimicrobial effect of enterocin CCM4231 in the cattle slurry environment. Cytobios 94: 73-79

LAUKOVÁ, A., CZIKKOVÁ, S., DOBRÁNSKY, T., BURDOVÁ, O. 1999: Inhibition of Listeria monocytogenes and Staphylococcus aureus by enterocin CCM4231 in milk products. Food Microbiol. 16: 93-99

LAUKOVÁ, A., CZIKKOVÁ, S. 1999: The use of enterocin CCM4231 in soy milk to control the growth of Listeria monocytogenes and Staphylococcus aureus. J. Appl. Microbiol. 87: 182-186

LAUKOVÁ, A., JURIŠ, P., VASILKOVÁ, Z. 2000a: Contamination and survival of pathogenic agents as well as other microbial agents in the wastes from pig farms. In: Environmental protection against the spread of pathogenic agents of diseases through the wastes of animal production in the Slovak republic. (Ed. Dubinský, P., Juriš, P., Moncol, D. J. ). Parasitological Inst. SAS, Košice: 55-78

LAUKOVÂ, A., JURIŜ, P., VASILKOVÁ, Z., PAPAJOVÁ, I. 2000b: Treatment of sanitary-important bacteria by bacteriocin substance V24 in cattle dung water. Lett. Appl. Microbiol. 30: 402-405

LAUKOVÁ, A., JURIŠ, P., PAPAJOVÁ, I. 2000c: The use of bacteriocin against contaminants of animal waste. In: Proceedings of conference "The prospects of probiotics in prevention and therapy of diseases of young", High Tatra, Slovak Republic, 11-14 October: 67

NATIONAL COMMITTEE FOR CLINICAL LABORATORY STANDARDS 1988: Tentative standard M2-T4 performance standards for antimicrobial disk susceptibility test, $4^{\text {th }}$ Ed. Villanova, PA: National Committee for Clinical Laboratory Standards

NIELSEN, K.M., van ELSAS, J.D., SMALLA, K. 2000: Transformation of Acinetobacter sp. strain BD413 (pFG4nptII) with transgenic plant DNA in soil microcosms and effects of kanamycin on selection of transformants. Appl. Environ. Microbiol. 66: 1237-1242

ROSSAU, R., van LANDSCHOOT, A., GILLIS, M., DE LEY, J. 1991: Taxonomy of Moraxellaceae fam. Nov. a new bacterial Family to accommodate the genera Moraxella, Acinetobacter, and Psychrobacter and related organisms. Int. J. Syst. Bacteriol. 41: 310-319

ROSSETTI, S., HILDISCH, D., CHRISTENSSON, C., DEL DOT, T., BLACKALL, L.L., TANDOI, V. 1997: Isolation and identification of an Eikelboom type 1863 strain as Acinetobacter johnsonii. Water Res. (G.B.) 31: 657

STRAUCH, D., BALLARINI, G. 1994: Hygienic aspects of the production and agricultural use of animal wastes. J. Vet. Med. B 41: 176-228

TOWNER, K.J. 1997: Clinical importance and antibiotic resistance of Acinetobacter spp. J. Med. Microbiol. 46 : 721-746 